\title{
KETERKAITAN KINERJA KEUANGAN DENGAN HARGA SAHAM: STUDI PADA PERUSAHAAN SEKTOR PERTANIAN YANG TERDAFTAR DI BEI
}

\author{
Tri Puji Rahayu \\ Universitas Ahmad Dahlan \\ Email: tripujirahayu541@gmail.com \\ Beni Suhendra Winarso \\ Universitas Ahmad Dahlan \\ Email: beni.winarso@act.uad.ac.id
}

\begin{abstract}
This study aims to investigate the effect of profitability ratios, liquidity ratios, activity ratios and leverage ratios on the stock prices of agricultural sector companies listed on the Indonesia Stock Exchange (IDX) in 2016-2020. The sampling technique in this study is the purposive sampling method. The type of data is quantitative research. The data sources used in the study are secondary data from the IDX website and the official website of related companies. The results show that the return on investment, earnings per share, quick ratio, and total assets turnover positively affect stock prices, while the return on equity, return on assets, current ratio, and debt ratio have a negative effect on stock prices.
\end{abstract}

Keywords: Profitability, Liquidity, Activity, Leverage, Stock Price.

\section{PENDAHULUAN}

Berdasarkan Undang-Undang Nomor 8 Tahun 1995, pasar modal merupakan suatu kegiatan yang berkaitan dengan perdagangan efek, perusahaan publik, serta lembaga dan profesi yang berhubungan dengan efek. Salah satu jenis sekuritas yang paling populer di pasar modal adalah sekuritas saham. Menurut Bursa Efek Indonesia, saham merupakan tanda penyertaan modal dalam suatu perusahaan atau perseroan terbatas.

Sebelum para investor melakukan transaksi jual beli saham di pasar modal, investor perlu melaksanakan penilaian terlebih dahulu pada perusahaan terkait. Investor perlu mengetahui benar atau tidaknya informasi yang telah ia peroleh dan pastikan sebelum mengambil keputusan bahwa tidak ada pihak terkait yang melakukan manipulasi data tersebut. Salah satu faktor yang dapat memengaruhi keputusan para investor yaitu persepsi mereka akan kewajaran harga saham. Oleh karena itu, informasi yang tidak tepat dapat menyesatkan keputusan para investor dalam melakukan investasi. Hal ini tentu saja akan merugikan para investor. Perubahan harga saham dipengaruhi oleh penawaran serta permintaan antara penjual dengan pembeli saham.

Kinerja keuangan perusahaan dapat dinilai dari laporan keuangannya. Laporan keuangan berisikan informasi relevan yang dibutuhkan oleh investor dalam membuat keputusan untuk berinvestasi. Analisis rasio adalah salah satu alat yang digunakan dalam mengidentifikasi baik atau buruknya suatu laporan keuangan. Terdapat empat jenis rasio yang digunakan dalam menilai kinerja keuangan perusahaan, yaitu rasio profitabilitas, rasio likuiditas, rasio aktivitas atau efisiensi, serta rasio leverage. Rasio profitabilitas digunakan untuk menilai kemampuan perusahaan untuk memeroleh laba dari penggunaan modalnya. Rasio likuiditas digunakan untuk mengukur kemampuan perusahaan untuk memenuhi kewajiban jangka pendeknya. Rasio aktivitas digunakan untuk mengukur efisiensi perusahaan dalam penggunaan aset. Rasio leverage 
Tri Puji Rahayu, Beni Suhendra Winarso | Keterkaitan Kinerja Keuangan dengan Harga Saham: Studi Pada Perusahaan Sektor Pertanian yang Terdaftar di BEI

digunakan untuk mengukur berapa banyak perusahaan menggunakan dana dari pinjaman.

Penelitian ini terinspirasi oleh penelitian yang dilakukan oleh Amanah, dkk. (2014). Adapun perbedaan penelitian ini dengan penelitian sebelumnya adalah terletak pada rasio dan objek penelitian yang digunakan. Penelitian ini diukur dengan menggunakan rasio return on investment (ROI), return on equity (ROE), return on assets (ROA), earnings per share (EPS), current ratio (CR), quick ratio (QR), total assets turnover (TATO) dan debt ratio (DR), sedangkan penelitian terdahulu diukur dengan menggunakan rasio CR, QR, ROA, dan ROE. Perbedaan lainnya adalah pada objek yang diteliti. Objek penelitian yang digunakan dalam penelitian terdahulu adalah perusahaan Indeks LQ45 periode 20082012, sedangkan penelitian ini menggunakan perusahaan pertanian yang terdaftar di BEI pada tahun 2016-2020. Negara Indonesia dikenal sebagai negara agraris yang sebagian besar wilayahnya digunakan untuk sektor pertanian. Pada Februari 2016, Badan Pusat Statistik mencatat 31,74 persen atau sekitar 38,29 juta masyarakat Indonesia bekerja di sektor pertanian (Julianto \& Jatmiko, 2017). Selain itu, Indonesia juga merupakan penghasil sawit, teh, kopi, dan karet terbesar di dunia (Jurnal Bumi, 2020). Hal tersebut menjadi motivasi bagi peneliti untuk melakukan penelitian mengenai keterkaitan kinerja keuangan dengan harga saham pada perusahaan pertanian yang terdaftar di BEI tahun 2016-2020. Penelitian ini berkontribusi untuk memberikan bukti empiris mengenai keterkaitan kinerja keuangan perusahaan yang diukur menggunakan rasio profitabillitas, likuiditas, aktivitas, dan leverage dengan harga saham.

\section{TINJAUAN PUSTAKA}

\section{Kajian Teoritis}

\section{Rasio Keuangan}

Rasio keuangan adalah aktivitas membandingkan angka yang terdapat di laporan keuangan dengan cara membagi satu angka dengan yang lainnya (Kasmir, 2015: 104 dalam Sutapa, 2018). Terdapat empat jenis rasio yang dapat digunakan untuk menilai kinerja keuangan perusahaan (Harjito \& Martono, 2011) sebagai berikut.

1. Rasio profitabilitas merupakan rasio yang menunjukkan kemampuan perusahaan dalam memeroleh laba dari penggunaan modalnya. Jenis rasio profitabilitas yang digunakan yaitu:

Return on investment (ROI) merupakan rasio yang berfungsi untuk membandingkan laba setelah pajak dengan total aset. Untuk menghitung return on investment (ROI), rumus yang digunakan yaitu:

$$
\text { Return on Investment }(R O I)=\frac{\text { Laba bersih Setelah Pajak }}{\text { Total Aset }}
$$

Return on equity (ROE) yaitu rasio yang digunakan untuk mengukur seberapa banyak keuntungan yang merupakan hak pemilik modal sendiri. Rumus yang digunakan yaitu:

$$
\text { Return on Equity }(R O E)=\frac{\text { Laba bersih Setelah Pajak }}{\text { Total Modal Sendiri }}
$$

Return on assets (ROA) merupakan rasio yang digunakan untuk mengukur persentase laba yang diperoleh suatu perusahaan sehingga dapat menilai efisiensi perusahaan dalam mengelola aset yang dimilikinya. Rumus yang digunakan yaitu:

$$
\text { Return on Assets }(R O A)=\frac{\text { Laba Bersih }}{\text { Total Aset }}
$$

Earnings per share (EPS) adalah rasio yang digunakan untuk mengukur kemampuan per lembar saham dalam memperoleh laba suatu perusahaan. Rumus yang digunakan yaitu: 
Tri Puji Rahayu, Beni Suhendra Winarso | Keterkaitan Kinerja Keuangan dengan Harga Saham: Studi Pada Perusahaan Sektor Pertanian yang Terdaftar di BEI

$$
E P S=\frac{\text { Laba bersih Setelah Pajak }- \text { Dividen Saham Preferen }}{\text { Saham Biasa yang Beredar }}
$$

2. Rasio likuiditas adalah rasio yang menunjukkan keterkaitan kas perusahaan serta aset lancar lainnya dengan utang lancar. Rasio likuiditas berfungsi untuk menilai kemampuan perusahaan dalam memenuhi utang lancarnya. Jenis rasio likuiditas yang digunakan adalah:

Current ratio (CR) merupakan rasio yang berfungsi untuk membandingkan aset lancar dengan utang lancar. Rumus yang digunakan adalah:

$$
\text { Current Ratio }(C R)=\frac{\text { Aset Lancar }}{\text { Utang Lancar }}
$$

Quick Ratio (QR) adalah rasio yang berfungsi untuk mengukur tingkat likuiditas perusahaan. Rumus yang digunakan yaitu:

$$
\text { Quick Ratio }(Q R)=\frac{\text { Aset Lancar }- \text { Persediaan }}{\text { Utang Lancar }}
$$

3. Rasio aktivitas atau sering juga dikenal sebagai rasio efisiensi merupakan rasio yang digunakan untuk mengukur efisiensi perusahaan dalam menggunakan asetnya. Jenis rasio aktivitas yang digunakan yaitu:

Rasio total assets turnover adalah rasio yang digunakan untuk mengukur perputaran aset milik perusahaan. Rumus yang digunakan yaitu:

$$
\text { Rasio total assets turnover }=\frac{\text { Penjualan Bersih }}{\text { Total Aset }}
$$

4. Rasio leverage, merupakan rasio yang berfungsi dalam mengukur seberapa besar perusahaan menggunakan dana dengan sumber pinjaman. Jenis rasio leverage yang digunakan yaitu:

Debt ratio merupakan rasio yang digunakan untuk mengukur persentase aset perusahaan yang dibiayai oleh utang perusahaan. Rumus yang digunakan yaitu:

$$
\text { Debt ratio }=\frac{\text { Total Utang }}{\text { Total Aset }}
$$

\section{Harga Saham}

Saham merupakan surat berharga yang menunjukkan hak pemodal sebagai bukti kepemilikan pribadi atau badan dalam suatu perusahaan (Amanah dkk., 2012). Harga saham adalah harga penutupan (closing price) dari kepemilikan seseorang atau badan dalam suatu perusahaan yang berlaku di pasar modal Indonesia (Ramadhana dkk., 2018).

\section{Pengembangan Hipotesis}

\section{Pengaruh Profitabilitas terhadap Harga Saham}

Rasio profitabilitas adalah rasio yang menunjukkan kemampuan perusahaan dalam memeroleh laba dari penggunaan modalnya. Sutapa (2018) menyatakan bahwa pada prinsipnya semakin baik kemampuan perusahaan dalam memeroleh laba maka semakin baik kemampuan perusahaan dalam menggunakan asetnya secara produktif. Amanah dkk. (2014) menemukan bahwa ROA memiliki pengaruh positif terhadap harga saham. Penelitian tersebut juga didukung oleh beberapa peneliti lain, seperti Utomo (2019) yang menemukan bahwa ROI dan ROE berpengaruh positif terhadap harga saham, serta Rani dan Diantini (2015) yang menemukan bahwa EPS memengaruhi harga saham secara positif. Hal ini menunjukkan semakin tinggi nilai ROI, ROE, ROA dan EPS maka semakin tinggi pula kemampuan perusahaan dalam memeroleh keuntungan sehingga mampu meningkatkan harga saham perusahaan, jadi hipotesisnya adalah: 
Tri Puji Rahayu, Beni Suhendra Winarso | Keterkaitan Kinerja Keuangan dengan Harga Saham: Studi Pada Perusahaan Sektor Pertanian yang Terdaftar di BEI

H1:Profitabilitas yang diukur dengan return on investment (ROI), return on equity (ROE), return on assets (ROA) dan earnings per share (EPS) berpengaruh terhadap harga saham perusahaan sektor pertanian yang terdaftar di BEI tahun 2016-2020.

\section{Pengaruh Likuiditas terhadap Harga Saham}

Rasio likuiditas merupakan rasio untuk mengukur kemampuan perusahaan dalam memenuhi kewajiban finansial yang harus segera dipenuhi atau kewajiban jangka pendeknya. Gitman (2009) dalam Sutapa (2018) menyatakan bahwa perusahaan yang mempunyai tingkat likuiditas yang baik maka akan memungkinkan pembayaran dividen yang lebih baik pula, dan tentunya investor akan tertarik untuk menanamkan modalnya pada perusahaan tersebut. Apabila permintaan saham meningkat maka harga saham akan meningkat. Amanah dkk. (2014) dalam penelitiannya menemukan bahwa current ratio (CR) memengaruhi harga saham penutupan secara positif dan signifikan, sedangkan quick ratio $(\mathrm{QR})$ memengaruhi harga saham penutupan secara negatif dan signifikan. Hal ini menunjukkan bahwa semakin tinggi nilai current ratio (CR) maka semakin tinggi pula kemampuan perusahaan dalam memenuhi kewajiban finansialnya sehingga dapat meningkatkan harga saham perusahaan tersebut, sedangkan semakin tinggi quick ratio $(\mathrm{QR})$ maka semakin rendah kemampuan perusahaan dalam memenuhi kewajiban finansialnya sehingga dapat menurunkan harga saham begitu juga sebaliknya, jadi hipotesisnya adalah:

H2: Likuiditas yang diukur dengan current ratio $(\mathrm{CR})$ dan quick ratio $(\mathrm{QR})$ berpengaruh terhadap harga saham perusahaan sektor pertanian yang terdaftar di BEI tahun 2016-2020.

\section{Pengaruh Aktivitas terhadap Harga Saham}

Rasio aktivitas merupakan rasio yang digunakan untuk mengukur efisiensi perusahaan dalam menggunakan asetnya. Rasio aktivitas yang digunakan dalam penelitian ini yaitu total assets turnover. Handayani dan Hadi (2019) berpendapat bahwa rasio aktivitas memiliki manfaat bagi manajemen perusahaan dalam memperbaiki serta meningkatkan kinerja perusahaannya karena rasio aktivitas akan berjalan seiring dengan rasio profitabilitas. Ketika suatu perusahaan menggunakan sumber daya secara efisien maka perusahaan akan cenderung memiliki keuntungan yang tinggi. Rani dan Diantini (2015) menemukan bahwa total assets turnover memengaruhi harga saham secara signifikan. Hal ini menunjukkan bahwa semakin tinggi total assets turnover maka semakin tinggi pula efisiensi perusahaan dalam menggunakan asetnya sehingga dapat meningkatkan harga saham perusahaan tersebut, jadi hipotesisnya adalah:

H3: Aktivitas yang diukur dengan total assets turnover (TATO) berpengaruh terhadap harga saham perusahaan sektor pertanian yang terdaftar di BEI tahun 2016-2020.

\section{Pengaruh Leverage terhadap Harga Saham}

Rasio leverage merupakan rasio yang digunakan untuk mengukur seberapa banyak perusahaan menggunakan dana dari pinjaman. Zaki dkk. (2017) berpendapat leverage yang tinggi menunjukkan komposisi tingkat utang lebih besar dibandingkan dengan total modal sendiri. Hal ini akan berdampak pada semakin besar beban perusahaan terhadap pihak eksternal. Mahadewi dan Candraningrat (2014) menemukan bahwa debt ratio memiliki pengaruh negatif terhadap harga saham. Hal ini menunjukkan semakin tinggi debt ratio maka semakin tinggi pula penggunaan dana oleh perusahaan yang bersumber dari pinjaman, hal ini dapat menurunkan harga saham perusahaan, jadi hipotesisnya adalah:

H4: Leverage yang diukur dengan debt ratio (DR) berpengaruh terhadap harga saham perusahaan sektor pertanian yang terdaftar di BEI tahun 2016-2020. 
Tri Puji Rahayu, Beni Suhendra Winarso | Keterkaitan Kinerja Keuangan dengan Harga Saham: Studi Pada Perusahaan Sektor Pertanian yang Terdaftar di BEI

\section{METODE PENELITIAN}

\section{Objek Penelitian}

Penelitian ini merupakan penelitian kuantitatif berdasar pada pengolahan data sekunder yang diperoleh dari website Bursa Efek Indonesia (BEI) serta website resmi perusahaan terkait. Pengambilan sampel dalam penelitian ini menggunakan metode purposive sampling dengan kriteria memiliki data laporan keuangan yang lengkap dan perusahaan tidak mengalami kerugian secara berturut turut pada saat periode penelitian. Berdasarkan kriteria tersebut, diperoleh sampel dalam penelitian ini yang terdiri dari 9 perusahaan sektor pertanian yang terdaftar di Bursa Efek Indonesia pada tahun 2016-2020, yaitu Astra Agro Lestari Tbk, BISI International Tbk, Dharma Samudra Fishing Industries Tbk, Dharma Satya Nusantara Tbk, PP London Sumatra Indonesia Tbk, Sampoerna Agro Tbk, Salim Ivomas Pratama Tbk, Smart Tbk, dan Sawit Sumbermas Sarana Tbk.

\section{Definisi Operasional dan Pengukuran Variabel}

Variabel dependen dalam penelitian ini adalah harga saham yang merupakan surat berharga yang menunjukkan hak pemodal sebagai bukti kepemilikan pribadi atau badan dalam suatu perusahaan (Amanah dkk., 2012). Harga saham dalam penelitian ini diukur dengan menggunakan harga saham penutupan (closing price).

Variabel independen dalam penelitian ini adalah kinerja keuangan yang ditentukan dengan profitabilitas, likuiditas, aktivitas, dan leverage. Profitabilitas diukur dengan return on investment (ROI), return on equity (ROE), return on assets (ROA), dan earnings per share (EPS). Likuiditas diukur dengan current ratio (CR) dan quick ratio (QR). Aktivitas diukur dengan total assets turnover (TATO). Leverage diukur dengan debt ratio (DR).

\section{Teknik Analisis Data}

Analisis data dalam penelitian ini menggunakan analisis regresi linier berganda, dengan persamaan (1) sebagai berikut.

$y=\alpha+\beta_{1} X_{1}+\beta_{2} X_{2}+\beta_{3} X_{3}+\beta_{4} X_{4}+\cdots+e$

Dimana Y merupakan variabel dependen, $\alpha$ merupakan konstanta, $\beta_{1} . \beta_{4}$ merupakan koefisien regresi, $X_{1} . X_{4}$ merupakan variabel independen, dan e merupakan eror.

\section{HASIL DAN PEMBAHASAN}

Uji Asumsi Klasik

Uji Normalitas

Hasil uji normalitas dijelaskan dalam Tabel 1.

Tabel 1. Hasil Uji Normalitas

\begin{tabular}{|c|c|c|}
\hline Keterangan & Unstandardized Residual & Alpha \\
\hline $\mathrm{N}$ & 43 & 0,05 \\
\hline Asymp. Sig & 0,058 & \\
\hline
\end{tabular}

Sumber: Hasil olah data SPSS 25 (2021)

Berdasarkan hasil uji normalitas pada Tabel 1 diketahui nilai asymp. Sig (2-tailed) adalah 0,058. Hasil ini menunjukkan bahwa nilai tersebut lebih besar dari 0,05, maka data residual dikatakan berdistribusi normal.

\section{Uji Autokorelasi}

Hasil uji autokorelasi dijelaskan dalam Tabel 2. 
Tri Puji Rahayu, Beni Suhendra Winarso | Keterkaitan Kinerja Keuangan dengan Harga Saham: Studi Pada Perusahaan Sektor Pertanian yang Terdaftar di BEI

Tabel 2. Hasil Uji Autokorelasi

\begin{tabular}{cccc}
\hline Model & F & Alpha & Keterangan \\
\hline Sig. & 0,997 & 0,05 & Tidak ada autokorelasi \\
\hline \multicolumn{4}{c}{ Sumber: Hasil olah data SPSS } \\
\hline
\end{tabular}

Berdasarkan hasil uji autokorelasi pada Tabel 2 diketahui nilai asymp. Sig (2-tailed) adalah 0,997. Hasil ini menunjukkan bahwa nilai tersebut lebih besar dari 0,05. Dari hasil yang telah diperoleh dapat disimpulkan bahwa data dalam penelitian ini tidak terdapat autokorelasi.

\section{Uji Multikolinearitas}

Hasil uji multikolinearitas dijelaskan dalam Tabel 3.

Tabel 3. Hasil Uji Multikolinearitas

\begin{tabular}{cccc}
\hline Variabel Independen & VIF & Tolerance & Keterangan \\
\hline ROI & 8,396 & 0,119 & Tidak terdapat multikolinearitas \\
ROE & 5,513 & 0,181 & Tidak terdapat multikolinearitas \\
ROA & 3,295 & 0,303 & Tidak terdapat multikolinearitas \\
EPS & 1,884 & 0,531 & Tidak terdapat multikolinearitas \\
CR & 9,193 & 0,109 & Tidak terdapat multikolinearitas \\
QR & 5,436 & 0,184 & Tidak terdapat multikolinearitas \\
TATO & 1,191 & 0,840 & Tidak terdapat multikolinearitas \\
DR & 6,039 & 0,166 & Tidak terdapat multikolinearitas \\
\hline
\end{tabular}

Sumber: Hasil olah data SPSS 25 (2021)

Berdasarkan hasil uji multikolinearitas pada Tabel 3 dapat dilihat bahwa nilai VIF semua variabel independen di bawah 10. Hal ini menunjukkan bahwa tidak terjadi multikolinearitas antar variabel independen dalam model regresi tersebut.

Uji Heteroskedastisitas

Hasil uji heteroskedastisitas dijelaskan dalam Tabel 4.

Tabel 4. Hasil Uji Heteroskedastisitas

\begin{tabular}{cccc}
\hline $\begin{array}{c}\text { Variabel } \\
\text { Independen }\end{array}$ & Sig. (2-tailed) & $\begin{array}{c}\text { Correlation } \\
\text { Coefficient }\end{array}$ & Keterangan \\
\hline ROI & 0,674 & 0,066 & Tidak terjadi heteroskedastisitas \\
ROE & 0,577 & $-0,088$ & Tidak terjadi heteroskedastisitas \\
ROA & 0,986 & 0,003 & Tidak terjadi heteroskedastisitas \\
EPS & 0,366 & $-0,141$ & Tidak terjadi heteroskedastisitas \\
CR & 0,351 & 0,146 & Tidak terjadi heteroskedastisitas \\
QR & 0,888 & $-0,022$ & Tidak terjadi heteroskedastisitas \\
TATO & 0,052 & 0,299 & Tidak terjadi heteroskedastisitas \\
DR & 0,052 & $-0,298$ & Tidak terjadi heteroskedastisitas \\
\hline
\end{tabular}

Sumber: Hasil olah data SPSS 25 (2021)

Uji heteroskedastisitas yang digunakan dalam penelitian ini adalah Sperman's rank correlation test. Berdasarkan hasil pengolahan data untuk uji heteroskedastisitas diperoleh kesimpulan bahwa tidak terjadi heterokedastisitas pada data yang diuji.

\section{Uji Regresi Linier Berganda}

Uji regresi linier berganda dilakukan untuk mengetahui pengaruh variabel independen terhadap variabel dependen. Sebelum melakukan uji regresi linier berganda, diperlukan uji asumsi klasik terlebih dahulu. Model regresi penelitian ini telah memenuhi uji asumsi klasik, yaitu uji normalitas, uji multikolinearitas, uji autokorelasi, dan uji heteroskedastisitas. Hasil uji regresi linier berganda dijelaskan pada Tabel 5. 
Tri Puji Rahayu, Beni Suhendra Winarso | Keterkaitan Kinerja Keuangan dengan Harga Saham: Studi Pada Perusahaan Sektor Pertanian yang Terdaftar di BEI

Tabel 5. Hasil Uji Regresi Linier Berganda

\begin{tabular}{ccccc}
\hline Variabel & Koefisien & $\mathrm{t}$ & Sig. & Keputusan \\
\hline Konstanta & 4113,371 & 128,192 & 0,000 & \\
ROI & 1185,632 & 347,612 & 0,000 & H1 terdukung \\
ROE & $-514,558$ & $-350,570$ & 0,000 & H1 terdukung \\
ROA & $-278,352$ & $-136,132$ & 0,000 & H1 terdukung \\
EPS & 7,151 & 130,535 & 0,000 & H1 terdukung \\
CR & $-12,657$ & $-102,301$ & 0,000 & H2 terdukung \\
QR & 8,160 & 62,743 & 0,000 & H2 terdukung \\
TATO & 1,995 & 17,438 & 0,000 & H3 terdukung \\
DR & $-4,095$ & $-7,660$ & 0,000 & H4 terdukung \\
\hline
\end{tabular}

Sumber: Hasil olah data SPSS 25 (2021)

Berdasarkan hasil pengujian pada Tabel 5 dapat dirumuskan persamaan regresi sebagai berikut.

$\mathrm{Y}=4113,371+1185,632 \mathrm{ROI}-514,558 \mathrm{ROE}-278,352 \mathrm{ROA}+7,151 \mathrm{EPS}-12,657 \mathrm{CR}+$ $8,160 \mathrm{QR}+1,995 \mathrm{TATO}-4,095 \mathrm{DR}$

Interprestasi dari persamaan regresi tersebut adalah sebagai berikut.

1. Variabel ROI memiliki nilai signifikansi 0,000, angka ini lebih kecil dari 0,05. Hal ini berarti bahwa H1 terdukung, sehingga dapat dikatakan bahwa variabel ROI berpengaruh terhadap harga saham.

2. Variabel ROE memiliki nilai signifikansi 0,000, angka ini lebih kecil dari 0,05. Hal ini berarti bahwa H1 terdukung, sehingga dapat dikatakan bahwa variabel ROE berpengaruh terhadap harga saham.

3. Variabel ROA memiliki nilai signifikansi 0,000, angka ini lebih kecil dari 0,05. Hal ini berarti bahwa H1 terdukung, sehingga dapat dikatakan bahwa variabel ROA berpengaruh terhadap harga saham.

4. Variabel EPS memiliki nilai signifikansi 0,000, angka ini lebih kecil dari 0,05. Hal ini berarti bahwa H1 terdukung, sehingga dapat dikatakan bahwa variabel EPS berpengaruh terhadap harga saham.

5. Variabel CR memiliki nilai signifikansi 0,000, angka ini lebih kecil dari 0,05. Hal ini berarti bahwa H1 terdukung, sehingga dapat dikatakan bahwa variabel CR berpengaruh terhadap harga saham.

6. Variabel QR memiliki nilai signifikansi 0,000, angka ini lebih kecil dari 0,05. Hal ini berarti bahwa H1 terdukung, sehingga dapat dikatakan bahwa variabel QR berpengaruh terhadap harga saham.

7. Variabel TATO memiliki nilai signifikansi 0,000, angka ini lebih kecil dari 0,05. Hal ini berarti bahwa H1 terdukung, sehingga dapat dikatakan bahwa variabel TATO berpengaruh terhadap harga saham.

8. Variabel DR memiliki nilai signifikansi 0,000, angka ini lebih kecil dari 0,05. Hal ini berarti bahwa H1 terdukung, sehingga dapat dikatakan bahwa variabel DR berpengaruh terhadap harga saham.

\section{Pembahasan}

H1: Profitabilitas yang diukur dengan return on investment (ROI), return on equity (ROE), return on assets (ROA), dan earnings per share (EPS) berpengaruh terhadap harga saham perusahaan sektor pertanian yang terdaftar di BEI tahun 2016-2020.

\section{Return on Investment (ROI)}

Berdasarkan hasil uji regresi linier berganda pada Tabel 5 diperoleh koefisien variabel ROI sebesar 1185,632 dengan nilai signifikansi 0,000<0,05. Dari hasil tersebut diperoleh kesimpulan bahwa return on investment (ROI) berpengaruh positif terhadap harga saham. Hal ini mengindikasikan bahwa semakin tinggi nilai ROI maka semakin tinggi pula tingkat harga saham perusahaan, dan apabila nilai ROI mengalami penurunan 
Tri Puji Rahayu, Beni Suhendra Winarso | Keterkaitan Kinerja Keuangan dengan Harga Saham: Studi Pada Perusahaan Sektor Pertanian yang Terdaftar di BEI

maka harga saham suatu perusahaan juga akan mengalami penurunan. Hasil penelitian ini sejalan dengan penelitian yang dilakukan oleh Utomo (2019) yang menyatakan bahwa ROI berpengaruh positif terhadap harga saham.

\section{Return on Equity (ROE)}

Berdasarkan hasil uji regresi linier berganda pada Tabel 5 diperoleh koefisien variabel ROE sebesar $-514,558$ dengan nilai signifikansi $0,000<0,05$. Dari hasil tersebut diperoleh kesimpulan bahwa return on equity (ROE) berpengaruh negatif terhadap harga saham. Hal ini mengindikasikan bahwa semakin tinggi nilai ROE maka tingkat harga saham perusahaan akan semakin turun, dan sebaliknya apabila nilai ROE mengalami penurunan maka harga saham suatu perusahaan akan mengalami kenaikan. Hasil penelitian ini sejalan dengan penelitian yang dilakukan oleh Putri dan Septianti (2020) yang menyatakan bahwa ROE berpengaruh negatif terhadap harga saham.

\section{Return on Assets (ROA)}

Berdasarkan hasil uji regresi linier berganda pada Tabel 5 diperoleh koefisien variabel ROA sebesar -278,352 dengan nilai signifikansi $0,000<0,05$. Dari hasil tersebut diperoleh kesimpulan bahwa return on assets (ROA) berpengaruh negatif terhadap harga saham. Hal ini mengindikasikan bahwa semakin tinggi nilai ROA maka semakin rendah tingkat harga saham perusahaan, dan sebaliknya apabila nilai ROI mengalami penurunan maka harga saham suatu perusahaan akan mengalami peningkatan. Hasil penelitian ini sejalan dengan penelitian yang dilakukan oleh Ekawati dan Yuniati (2010) yang menyatakan bahwa ROA berpengaruh negatif terhadap harga saham.

\section{Earnings Per Share (EPS)}

Berdasarkan hasil uji regresi linier berganda pada Tabel 5 diperoleh koefisien variabel EPS sebesar 7,151 dengan nilai signifikansi 0,000<0,05. Dari hasil tersebut diperoleh kesimpulan bahwa earnings per share (EPS) berpengaruh positif terhadap harga saham. Hal ini mengindikasikan bahwa semakin tinggi nilai EPS maka semakin tinggi pula tingkat harga saham perusahaan, dan sebaliknya apabila nilai EPS mengalami penurunan maka harga saham suatu perusahaan juga akan mengalami penurunan. Hasil penelitian ini sejalan dengan penelitian yang dilakukan oleh Rani dan Diantini (2015) yang menyatakan bahwa EPS berpengaruh positif terhadap harga saham.

H2: Likuiditas yang diukur dengan current ratio $(\mathrm{CR})$ dan quick ratio $(\mathrm{QR})$ berpengaruh terhadap harga saham perusahaan sektor pertanian yang terdaftar di BEI tahun 2016-2020.

\section{Current Ratio (CR)}

Berdasarkan hasil uji regresi linier berganda pada Tabel 5 diperoleh koefisien variabel CR sebesar -12,657 dengan nilai signifikansi $0,000<0,05$. Dari hasil tersebut diperoleh kesimpulan bahwa current ratio (CR) berpengaruh negatif terhadap harga saham. Hal ini mengindikasikan bahwa semakin tinggi nilai CR maka semakin rendah tingkat harga saham perusahaan, dan apabila nilai CR mengalami penurunan maka harga saham suatu perusahaan akan mengalami peningkatan. Hasil penelitian ini sejalan dengan penelitian yang dilakukan oleh Amrah dan Elwisam (2018) yang menyatakan bahwa CR berpengaruh negatif terhadap harga saham.

\section{Quick Ratio (QR)}

Berdasarkan hasil uji regresi linier berganda pada Tabel 5 diperoleh koefisien variabel QR sebesar 8,160 dengan nilai signifikansi $0,000<0,05$. Dari hasil tersebut diperoleh kesimpulan bahwa quick ratio $(\mathrm{QR})$ berpengaruh positif terhadap harga saham. Hal ini mengindikasikan bahwa semakin tinggi nilai QR maka semakin tinggi tingkat harga saham perusahaan, dan apabila nilai QR mengalami penurunan maka harga saham suatu perusahaan akan mengalami penurunan. Hasil penelitian ini sejalan dengan penelitian yang dilakukan oleh Suryanengsih dan Kharisma (2020). 
Tri Puji Rahayu, Beni Suhendra Winarso | Keterkaitan Kinerja Keuangan dengan Harga Saham: Studi Pada Perusahaan Sektor Pertanian yang Terdaftar di BEI

H3: Aktivitas yang diukur dengan total assets turnover (TATO) berpengaruh terhadap harga saham perusahaan sektor pertanian yang terdaftar di BEI tahun 2016-2020.

Total Assets Turnover (TATO)

Berdasarkan hasil uji regresi linier berganda pada Tabel 5 diperoleh koefisien variabel TATO sebesar 1,995 dengan nilai signifikansi $0,000<0,05$. Dari hasil tersebut diperoleh kesimpulan bahwa total assets turnover (TATO) berpengaruh positif terhadap harga saham. Hal ini mengindikasikan bahwa semakin tinggi nilai TATO maka semakin tinggi pula tingkat harga saham perusahaan, dan apabila nilai TATO mengalami penurunan maka harga saham suatu perusahaan juga akan mengalami penurunan. Hasil penelitian ini sejalan dengan penelitian yang dilakukan oleh Rani dan Diantini (2015) yang menyatakan bahwa TATO berpengaruh positif terhadap harga saham.

H4: Leverage yang diukur dengan debt ratio berpengaruh terhadap harga saham perusahaan sektor pertanian yang terdaftar di BEI tahun 2016-2020.

\section{Debt Ratio (DR)}

Berdasarkan hasil uji regresi linier berganda pada Tabel 5 diperoleh koefisien variabel DR sebesar -4,095 dengan nilai signifikansi 0,000<0,05. Dari hasil tersebut diperoleh kesimpulan bahwa debt ratio (DR) berpengaruh negatif terhadap harga saham. Hal ini mengindikasikan bahwa semakin tinggi nilai DR maka semakin rendah tingkat harga saham perusahaan, dan apabila nilai DR mengalami penurunan maka harga saham suatu perusahaan akan mengalami peningkatan. Hasil penelitian ini sejalan dengan penelitian yang dilakukan oleh Mahadewi \& Candraningrat (2014) yang menyatakan bahwa debt ratio memiliki pengaruh negatif terhadap harga saham.

\section{SIMPULAN, KETERBATASAN, DAN SARAN}

Penelitian ini bertujuan untuk memeroleh bukti empiris mengenai pengaruh rasio profitabilitas, likuiditas, aktivitas, dan leverage terhadap harga saham. Berdasarkan hasil penelitian dan pembahasan maka dapat disimpulkan bahwa profitabilitas yang diukur dengan return on investment (ROI) dan earnings per share (EPS) berpengaruh positif terhadap harga saham, sedangkan return on equity (ROE) dan return on assets (ROA) berpengaruh negatif terhadap harga saham. Likuiditas yang diukur dengan current ratio (CR) berpengaruh negatif terhadap harga saham, sedangkan quick ratio (QR) berpengaruh positif terhadap harga saham. Aktivitas yang diukur dengan total assets turnover (TATO) berpengaruh positif terhadap harga saham. Leverage yang diukur dengan debt ratio (DR) berpengaruh negatif terhadap harga saham. Penelitian selanjutnya diharapkan dapat menggunakan data primer yang diperoleh dari perusahaan terkait sehingga kesalahan data dalam laporan keuangan dapat diminimalisir. Penelitian selanjutnya juga sebaiknya mempertimbangkan kondisi ekonomi negara saat ini sebagai kriteria pemilihan sampel penelitian.

\section{DAFTAR PUSTAKA}

Amanah, R., Atmanto, D., \& Azizah, D. F. (2014). Pengaruh Likuiditas dan Rasio Profitabilitas Terhadap Harga Saham (Studi pada Perusahaan Indeks LQ45 Periode 2008-2012). Jurnal Administrasi Bisnis (JAB), 12(1). http://administrasibisnis.studentjournal.ub.ac.id/index.php/jab/article/view/495 $/ 691$

Amrah, R., \& Elwisam. (2018). Pengaruh Current Ratio, Return On Assets, Debt To Equity Ratio dan Total Assets Turnover terhadap Harga Saham pada Perusahaan LQ45 Tahun 2013-2015. Oikonomia: Jurnal Manajemen, 14(1), 46-62. http://dx.doi.org/10.47313/oikonomia.v14i1.513

Ekawati, S., \& Yuniati, T. (2010). Pengaruh ROA, ROE, dan EPS terhadap harga saham pada perusahaan transportasi. Jurnal Ilmiah dan Riset Manajemen, 9(3), 1-16. http://jurnalmahasiswa.stiesia.ac.id/index.php/jirm/article/view/2995/3009 
Tri Puji Rahayu, Beni Suhendra Winarso | Keterkaitan Kinerja Keuangan dengan Harga Saham: Studi Pada Perusahaan Sektor Pertanian yang Terdaftar di BEI

Handayani, H., \& Hadi, S. (2019). Pengaruh Rasio Aktivitas Terhadap Profitabilitas Perusahaan Farmasi yang Terdaftar di BEI Periode 2013-2017. Bilancia: Jurnal Ilmiah Akuntansi, 3(2), 146-157. http://www.ejournal.pelitaindonesia.ac.id/ojs32/index.php/BILANCIA/article/vie $\mathrm{w} / 430$

Harjito, A., \& Martono. (2011). Manajemen Keuangan Edisi ke 2 (2nd ed.).

Julianto, P., \& Jatmiko, B. (2017). Negara Agraris, Mengapa Harga Pangan di Indonesia Rawan Bergejolak?

Kompas. https://money.kompas.com/read/2017/02/19/163912926/negara.agraris.mengap a.harga.pangan.di.indonesia.rawan.bergejolak.?page=all

Jurnal Bumi. (2020). https://jurnalbumi.com/top/negara-penghasil-sawit/

Mahadewi, I. G. A. A. B., \& Candraningrat, I. R. (2014). Pengaruh Return on Asset, Earning Per Share, dan Debt Ratio Terhadap Harga Saham Pada Perusahaan Indeks LQ-45 di Bursa Efek Indonesia. E-Jurnal Manajemen Universitas Udayana, 3(12), 3558-3577. https://ojs.unud.ac.id/index.php/Manajemen/article/view/9975

Putri, N. K., \& Septianti, D. (2020). Pengaruh Return On Assets Return On Equity Debt To Equity Ratio dan Book Value Per Share Terhadap Harga Saham. Akuntansi dan Bisnis, 5(2), 145-155. https://doi.org/10.32502/jab.v5i2.2878

Ramadhana, A. A., Sjahruddin, H., \& Purnomo, S., H. (2018). Pengaruh Kinerja Keuangan Terhadap Harga Saham. Jurnal Organisasi dan Manajemen, 1(1), 47-65. https://osf.io/8phn2/download

Rani, K. S., \& Diantini, N. N. A. (2015). Pengaruh Kinerja Keuangan Perusahaan Terhadap Harga Saham Dalam Indeks LQ45 di BEI. Jurnal Manajemen Unud, 4(6), 1525-1542. https://ojs.unud.ac.id/index.php/Manajemen/article/view/12116

Suryanengsih, T. D., \& Kharisma, F. (2020). Pengaruh Current Ratio dan Quick Ratio Terhadap Harga Saham pada Perusahaan Consumer Goods yang Tercatat di BEI Periode Tahun 2013-2017. Borneo Student Research, 1(3), 1564-1570. https://journals.umkt.ac.id/index.php/bsr/article/view/1057/511

Sutapa, I. N. (2018). Pengaruh Rasio dan Kinerja Keuangan Terhadap Harga Saham Pada Indeks LQ45 di Bursa Efek Indonesia (BEI) Periode 2015-2016. KRISNA: Kumpulan Riset Akuntansi, 9(2), 11-19. https://doi.org/10.22225/kr.9.2.467.11-19

Undang-Undang Republik Indonesia Nomor 8 Tahun 1995 Tentang Pasar Modal.

Utomo, A. S. (2019). Pengaruh CSR, ROI, ROE terhadap Harga Saham pada Perusahaan Manufaktur yang Terdaftar di Bursa Efek Indonesia. Jurnal PETA, 4(1), 82-94. https://doi.org/10.51289/peta.v4i1.377

Zaki, M., Islahuddin, \& Shabri, M. (2017). Pengaruh Profitabilitas , Leverage Keuangan dan Ukuran Perusahaan Terhadap Harga Saham (Studi pada Perusahaan Manufaktur yang Terdaftar di Bursa Efek Indonesisa Periode 2005-2014). Jurnal Magister Akuntansi, $\quad 6(2), \quad$ 58-66. http://jurnal.unsyiah.ac.id/JAA/article/download/8969/7087 